\title{
LOW-ENERGY PRECISION APPLICATION (LEPA) IRRIGATION: A FORTY-YEAR REVIEW
}

\author{
J. P. Bordovsky
}

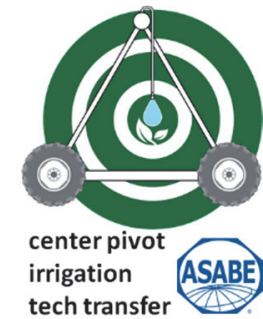

Collection

Review

ABSTRACT. The low-energy precision application (LEPA) irrigation concept was developed 40 years ago (ca. 1978) to address the depletion of irrigation water from the Ogallala Aquifer and the sharp increase in pumping costs caused by the 1970s fuel crisis occurring at that time in the Texas High Plains. The LEPA method applies water to the soil surface at low pressure using a tower-truss irrigation system that continually moves through the field. This method brought changes in irrigation equipment and management that resulted in improvements in water productivity, particularly in semi-arid locations with diminishing water supplies. A review of published information pertaining to LEPA history, evaluation, and usage was performed. On landscapes of less than $1 \%$ slope, negative crop yield effects caused by irrigation runoff and start-stop system alignment were overcome with appropriately spaced basins, or furrow checks, and multiple irrigations over the course of the growing season. No consistent yield advantage at any level of irrigation was documented by placing water in every furrow (1 $\mathrm{m}$ spacing) compared to alternate furrows (2 $\mathrm{m}$ spacing). In irrigation treatments having $\leq 50 \%$ of the estimated full irrigation quantity, LEPA resulted in a $16 \%$ yield increase over sprinkler methods, although subsurface drip irrigation (SDI) resulted in a 14\% yield increase over LEPA. At irrigation levels $>50 \%$ of full irrigation, crop yields of sprinkler treatments were only slightly less than those of LEPA, and SDI yields were 7\% greater than LEPA. The LEPA irrigation method was the catalyst for innovations in chemigation, no-till planting, and site-specific irrigation. As irrigation water becomes more limited, use and proper management of optimum irrigation methods will be critical.

Keywords. Basin tillage, Chemigation, Evapotranspiration, Irrigation methods, LEPA, Low-energy precision application, Runoff, Spray irrigation, Sprinkler irrigation, Uniformity, Water use efficiency.

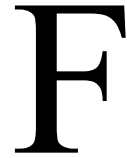
orty years ago (ca. 1978), the low-energy precision application (LEPA) irrigation concept was developed by William M. (Bill) Lyle out of the need to address two critical issues: the depletion of available irrigation water from the Ogallala Aquifer (McGuire, 2017) and the quadrupling of natural gas prices from 1973 to 1978 (EIA, 2018). At the time, surface (furrow) irrigation was the predominant method of irrigation in the U.S. (Howell, 2001) and in the Texas High Plains. There was a desire to overcome in-field variables such as non-homogeneity of soil texture, slope, well capacity, and crop residue, among others, which resulted in excess water to fill the root zone and excess energy for pumping water not ultimately used by a crop. Low-pressure mobile irrigation systems were being considered by others. Wilke (1974) moved a single drip lateral over rows of cotton with a tractor,

\footnotetext{
cc) $\$$ The authors have paid for open access for this article. This (c) ${ }_{\text {BY NG ND }}$ work is licensed under a Creative Commons AttributionNonCommercial-NoDerivatives 4.0 International License https://creative commons.org/licenses/by-nc-nd/4.0/

Submitted for review in September 2018 as manuscript number NRES 13117; approved for publication as an Invited Review and as part of the Center-Pivot Irrigation Tech Transfer Collection by the Natural Resources \& Environmental Systems Community of ASABE in December 2018.

The author is James P. Bordovsky, Senior Research Scientist and Agricultural Engineer, Texas A\&M AgriLife Research, 823 West U.S. Hwy 70, Plainview, TX 79072; phone: 806-889-3315; e-mail: j-bordovsky (a)tamu.edu.
}

but its potential use was limited to low-capacity wells and lowgrowing crops. Rawlings et al. (1974) used nylon tubing spaced $46 \mathrm{~cm}$ apart with flow rates of $0.64 \mathrm{~L} \mathrm{~m}^{-1}$ per tube and envisioned a field-scale design for center pivots.

The construction and initial evaluation of the first LEPA system began in 1978 at the Texas A\&M AgriLife Research Center (then the Texas Agricultural Experiment Station) at Halfway, Texas (Lyle and Bordovsky, 1981). Rather than spraying water into the air at moderate to high pressures, LEPA applies water to the soil surface at low pressure using a tower-truss irrigation system that continually moves through the field. The concept requires a method to contain the applied water until infiltration occurs to minimize irrigation and rainfall runoff. The system was designed to minimize the negative effects of soil and climatic variables, such as slow water infiltration and excessive evaporation, that occurred in surface and sprinkler irrigation systems, effects that are still relevant today.

The original LEPA design objectives included adaptability to a wide range of flow rates, adaptability to all soil types by using soil surface modification to prevent runoff, system operating pressure of less than $138 \mathrm{kPa}$, precise continuous movement, and adaptability to current production practices (Lyle and Bordovsky, 1981). The prototype LEPA system was an air-drive, continuous-move, linear system $150 \mathrm{~m}$ long, with water supplied from a low-head underground pipeline typically used to supply water for furrow irrigation 


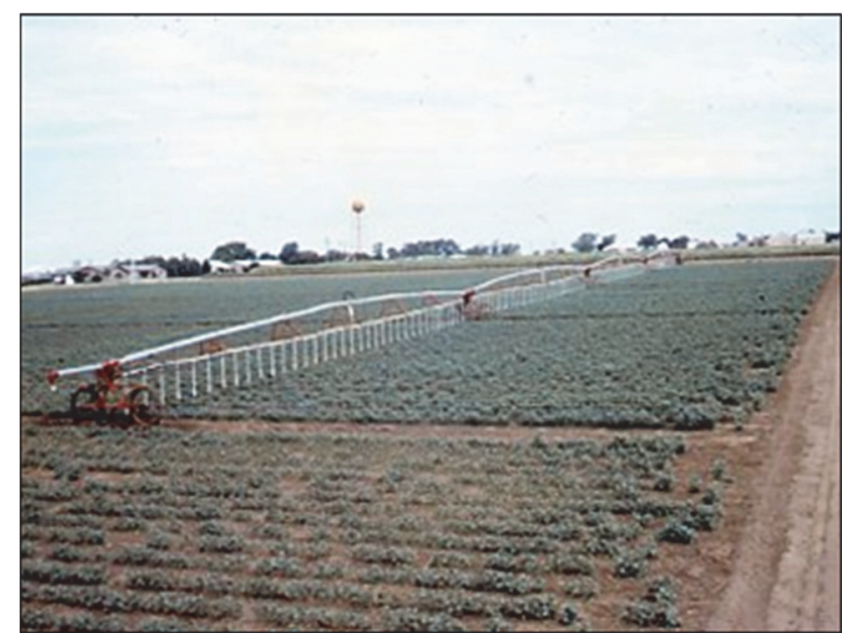

Figure 1. Prototype LEPA system during initial evaluation at the Texas A\&M AgriLife Research Center, Halfway, Texas, in 1979.

(fig. 1). A $150 \mathrm{~m}$ long, $13 \mathrm{~cm}$ diameter flexible hose was used to supply water from hydrants to the control platform of the LEPA system. Water was distributed along the lateral mainline into manifolds, drop tubes, and through orificecontrolled applicators located within $5 \mathrm{~cm}$ of the soil surface (Lyle and Bordovsky, 1981).

Evaluations of LEPA on growers' fields began in the early 1980s. This typically involved conversion of one span of an existing center pivot to LEPA and comparison of crop yield to adjacent, non-converted spans (Fipps and New, 1990). Modification of existing systems and construction of new components were necessary to accomplish this. At the time, centerpivot lateral outlets were often spaced at intervals greater than $5 \mathrm{~m}$, making direct alignment of drops and applicators with furrows impossible, efficient piping for water discharge below the lateral did not exist, nozzle applicators for non-erosive water discharge were lacking, and available orifice sizes were too coarse for close applicator spacing. Shop-built components were developed for the initial commercial demonstrations

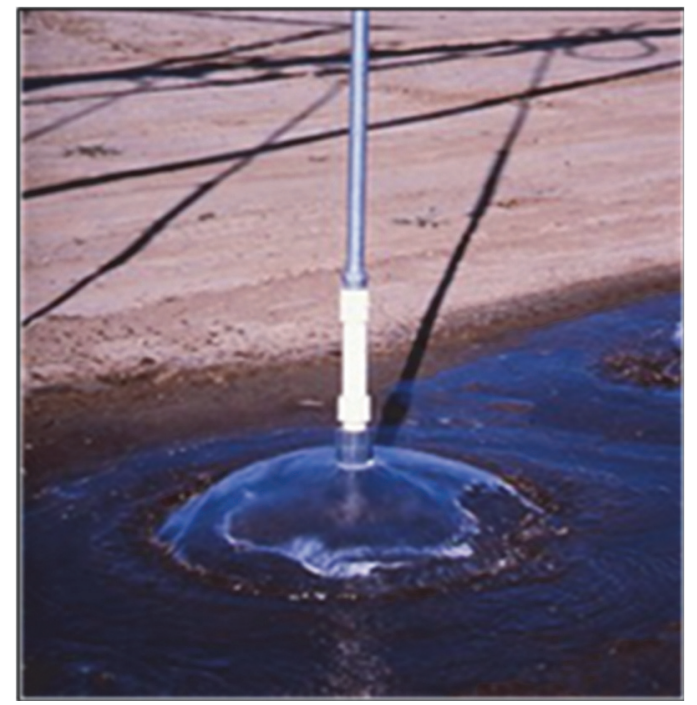

Figure 2. Irrigation applicator developed, built, and installed on initial LEPA pivot conversions. Orifice sizes were machined in $0.4 \mathrm{~mm}$ increments and placed appropriately to accommodate uniform water distribution along the pivot lateral at the Texas A\&M AgriLife Research Center, Halfway, Texas, in 1979.

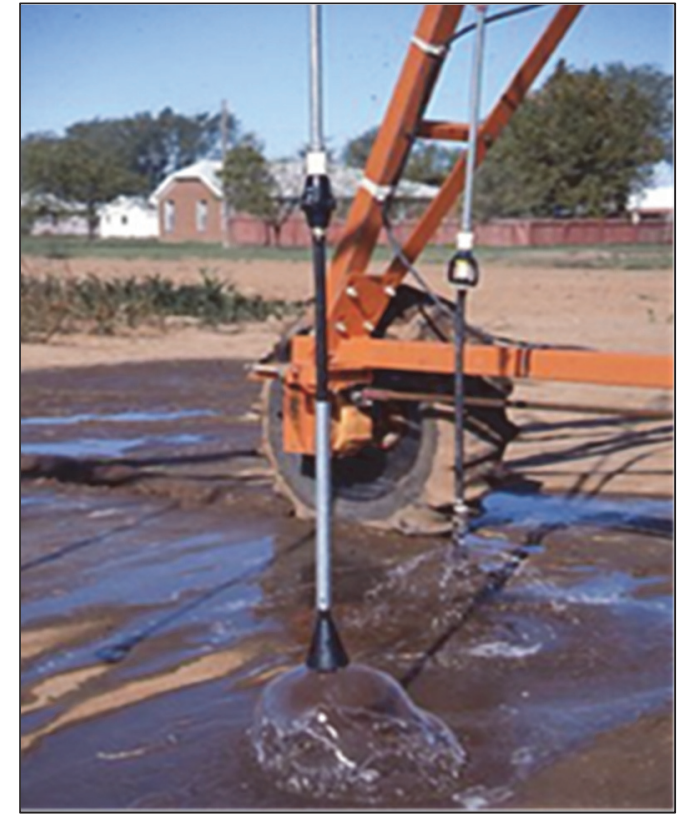

Figure 3. Prototype LEPA applicator manufactured by Rainbird in the early 1980s.

(fig. 2). Following the initial LEPA evaluations and demonstrations, manufacturers began offering $1.5 \mathrm{~m}$ pivot mainline lateral outlet spacing and developing furrow arms (goosenecks), low-flow low-pressure regulators, and applicators that disbursed water in non-erosive patterns (fig. 3).

Along with the introduction and initial evaluation of LEPA and the commercial development of LEPA components, economic evaluations and guidance for the adoption of LEPA were developed. Hill et al. (1990) evaluated the conversion cost from sprinklers to the LEPA method on irrigated cotton in the Texas High Plains and found benefit-cost ratios of 6.5 to 14 depending on cotton lint price. Fipps and New (1990) and New and Fipps (1991) described practical LEPA assembly requirements in terms of available piping options, mainline outlet options, droplines, regulators, and applicators. Management recommendations related to soil surface modifications, planting in a circle under center pivots, and soil water and pressure monitoring of LEPA systems were also made.

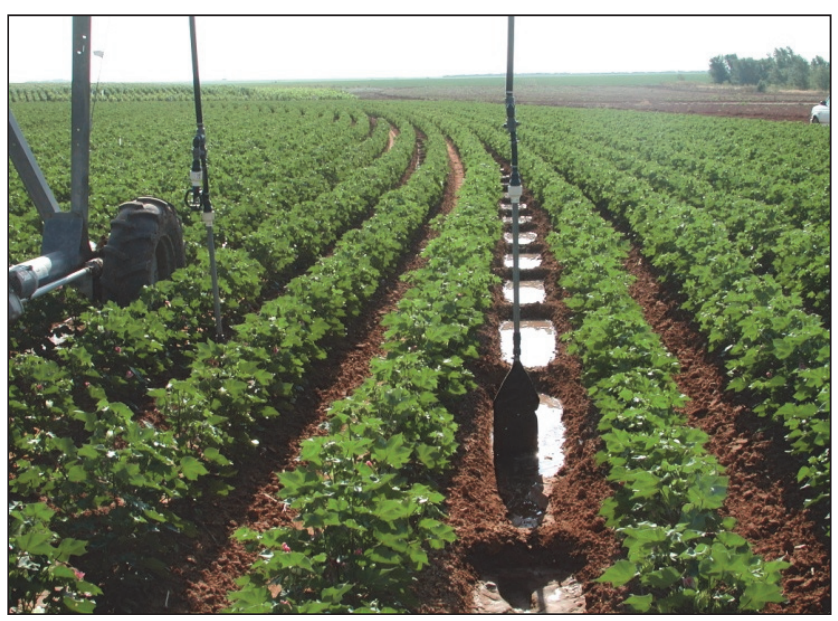

Figure 4. LEPA irrigation of cotton, at the Texas A\&M AgriLife Research Center, Halfway, Texas. 


\section{REQUIRED ELEMENTS OF LEPA IRRIGATION}

The LEPA irrigation method combines mechanical irrigation systems with soil surface management to provide efficient use of water, both rainfall and irrigation (fig. 4). Following initial evaluations, development of components by manufacturers, and initial acceptance by growers, LEPA irrigation became more clearly defined. An early proposed engineering design practice (ASABE, X531) addressed the planning, design, operation, and management of LEPA irrigation systems and specified that to be classified as LEPA, an irrigation system should:

- Be an overhead tower-supported pipeline system capable of either linear or pivotal movement.

- Be equipped with applicators capable of conveying and discharging water into a single crop furrow, which should be the predominant mode of operation (both temporally and spatially).

- Discharge water very near or on the soil surface to negate droplet evaporation in the air.

- Operate with overhead mainline end pressure no greater than $70 \mathrm{kPa}$ when the end tower is at its highest field elevation.

- Position the conveyance and discharge devices so that each plant within a field is approximately equidistant from an applicator and has equal opportunity for irrigation water delivery. Under pivot irrigation, this requires circular crop rows such that irrigated furrows are directly beneath applicators. The only deviation from the equal opportunity requirement is flow rate non-uniformity, with an acceptable discharge uniformity caused by nozzle sizing limitations and topographic changes.

- Combine soil surface management and operation of the mechanical LEPA system so that minimal runoff occurs from the irrigation water application point and rainfall retention is maximized.

\section{LEPA EVALUATIONS \\ UNIFORM WATER APPLICATION}

One of the major challenges in irrigation system design is uniform delivery of water to a crop. For pressurized systems, this is typically addressed by evaluating expected flow rates, inlet pressures, friction losses, and applicator characteristics of the system coupled with system management to minimize runoff. These same elements must be addressed with LEPA systems; however, additional challenges exist due to the high water application rate near the soil surface, particularly at the distal end of a center pivot. Irrigation infiltration and the effect of irrigation system movement must be considered. Soil surface modification to contain irrigation and rainfall until infiltration was an integral part of the original LEPA concept. Surface modifications included basin tillage, or the construction of small earthen dams (checks) between bedded crop rows at intervals of every few meters. This method was used in early LEPA experiments (Lyle and Dixon, 1977). Another method, implant reservoir tillage, involved the use of an inter-row ripper that opened the soil, followed by a wheel with bladed spokes that created voids in the loose soil (Wiser, 1985). Terminated wheat or other crop residue deliberately produced and left in furrows was some- times sufficient to prevent excessive water movement until infiltration occurred.

While working with LEPA, Hanson et al. (1988) concluded that the uniformity of applied water depended on hydraulic losses, movement of the pivot, basin tillage check spacing, and the random variability of soil intake rate. These factors resulted in a coefficient of uniformity of infiltrated water (Christiansen, 1942) from a single LEPA application of only $80 \%$ to $85 \%$. However, the uniformity increased with multiple irrigations. By using a combination of field experiments and simulations, Fangmeier et al. (1990) determined that basin checks must exceed $2 \mathrm{~m}$ in length to obtain uniformity greater than $80 \%$, with larger check spacing producing higher uniformities. Coelho et al. (1996) evaluated three configurations of tillage-implanted reservoirs and five water discharge rates of LEPA devices. Discharge rate affected the shape of the reservoir profile between crop rows; over the irrigation season, the hydraulic conductivity and drainable porosity were lowered in the bottom of reservoirs compared to that of the sides or top. The total dynamic storage of the three implant configurations was similar at approximately $27 \mathrm{~L}$ per reservoir.

Corn yield reductions were determined for various soil surface modification methods on sloping ground in replicated studies by Spurgeon et al. (1995). LEPA irrigation in treatment areas with $3.8 \%$ average slope and with no surface modifications resulted in yield reductions of $18 \%$ and $14 \%$ in two consecutive years, respectively, compared to areas with reservoir tillage. LEPA "worked well" on slopes of less than $2 \%$ when used with reservoir tillage or properly installed basin tillage.

Water losses from LEPA irrigation were measured or estimated in various studies. Residue from previous crops was used to reduce runoff from LEPA applications on a silt loam soil with irrigation losses of $30 \%$ and $55 \%$ on $3 \%$ and $8 \%$ slopes, respectively (Buchleiter, 1992). Schneider and Howell (2000) documented water losses ranging from $0 \%$ to $52 \%$ when using LEPA applicators without basin tillage for a $0.25 \%$ slope on a clay loam soil with irrigations at $40 \%$ to $100 \%$ of a controlled irrigation amount. In the same experiment, basin tillage reduced LEPA irrigation losses to $6 \%, 12 \%$, and $22 \%$ at $60 \%, 80 \%$, and $100 \%$ of the control irrigation amount, respectively. Mid-elevation spray application (MESA) coupled with basin tillage eliminated runoff. A summary of research of the pathways for water loss of LEPA and spray sprinkler methods was conducted by Schneider (2000). With little runoff or deep percolation, LEPA application efficiencies were reported as approximately $95 \%$ to $98 \%$, with losses from soil evaporation compared to spray efficiencies exceeding $90 \%$. The uniformity of water delivery along the irrigation system mainline was 0.94 to 0.97 for LEPA and 0.75 to 0.85 for spray. In the direction of travel, both LEPA and spray uniformity coefficients were in the 0.75 to 0.90 range, with basin tillage being critical for the LEPA method.

\section{APPLICATOR SPACING}

Early LEPA irrigation evaluations on corn, soybean, and cotton at the Texas A\&M AgriLife Research Center at Halfway, Texas, indicated yield advantages of $10 \%, 3 \%$, and $10 \%$, respectively, by placing irrigation applicators in alternate furrows compared to every furrow (Bordovsky et al., 1984). This result was attributed to reducing soil evaporation and/or deeper root zone wetting caused by alternate-furrow irrigation. Multi-year 
Table 1. Crop yields $\left(\mathrm{Mg} \mathrm{ha}^{-1}\right)$ from research studies comparing LEPA applicator spacing.

\begin{tabular}{|c|c|c|c|c|c|c|c|c|}
\hline \multirow[b]{2}{*}{ Source } & \multirow[b]{2}{*}{$\begin{array}{c}\text { Years of } \\
\text { Study }\end{array}$} & \multirow[b]{2}{*}{ Crop } & \multirow{2}{*}{$\begin{array}{c}\text { Average } \\
\text { Seasonal } \\
\text { Rainfall } \\
(\mathrm{mm})\end{array}$} & \multirow{2}{*}{$\begin{array}{c}\text { Average } \\
\text { Seasonal } \\
\text { Irrigation } \\
(\mathrm{mm})\end{array}$} & \multirow[b]{2}{*}{$\begin{array}{c}\% \text { of Base } \\
\text { Irrigation } \\
\text { Level }\end{array}$} & \multicolumn{2}{|c|}{ Crop Yield $\left(\mathrm{Mg} \mathrm{ha}^{-1}\right)^{[\mathrm{a}]}$} & \multirow{2}{*}{$\begin{array}{c}\text { Yield Increase } \\
\text { due to } 2 \mathrm{~m} \\
\text { Spacing } \\
(\%)\end{array}$} \\
\hline & & & & & & $\begin{array}{c}1 \mathrm{~m} \\
\text { Applicator } \\
\text { Spacing }\end{array}$ & $\begin{array}{c}2 \mathrm{~m} \\
\text { Applicator } \\
\text { Spacing }\end{array}$ & \\
\hline \multirow{4}{*}{$\begin{array}{c}\text { Bordovsky } \\
\text { et al., } \\
1992\end{array}$} & $1986-1988$ & Corn & 390 & 147 & 40 & $8.30 \mathrm{a}$ & $8.30 \mathrm{a}$ & 0.0 \\
\hline & & & & 261 & 70 & $10.20 \mathrm{~b}$ & $11.00 \mathrm{a}$ & 7.3 \\
\hline & & & & 368 & 100 & $11.70 \mathrm{a}$ & $11.60 \mathrm{a}$ & -0.9 \\
\hline & & & & 478 & 130 & $12.40 \mathrm{a}$ & $12.50 \mathrm{a}$ & 0.8 \\
\hline \multirow{4}{*}{$\begin{array}{c}\text { Bordovsky } \\
\text { and Lyle, } \\
1996\end{array}$} & 1992-1994 & Grain & 170 & 132 & 40 & $7.04 \mathrm{a}$ & $6.74 \mathrm{a}$ & -4.5 \\
\hline & & sorghum & & 230 & 70 & $7.61 \mathrm{a}$ & $7.41 \mathrm{a}$ & -2.6 \\
\hline & & & & 328 & 100 & $7.62 \mathrm{a}$ & $7.62 \mathrm{a}$ & 0.0 \\
\hline & & & & 427 & 130 & $7.43 \mathrm{a}$ & $7.67 \mathrm{a}$ & 3.1 \\
\hline
\end{tabular}

[a] Yield means in the same row followed by the same letter are not significantly different $(\mathrm{p}<0.05$, Duncan $)$.

replicated studies at this same location, with a clay loam soil, indicated significant yield advantages for corn at $2 \mathrm{~m}$ spacing over $1 \mathrm{~m}$ applicator spacing when irrigating at $70 \%$ of the base irrigation level (table 1). Furthermore, there was no consistent yield advantage in either corn (Bordovsky et al., 1992) or grain sorghum (Bordovsky and Lyle, 1996) at any level of irrigation by placing water in every furrow (1 m spacing) compared to alternate furrows ( $2 \mathrm{~m}$ spacing). This result improved grower acceptance of LEPA by reducing the cost of adoption by half, reducing potential soil surface evaporation, and providing unfettered access of farm equipment during the growing season by not requiring soil surface modification in wheel traffic furrows.

\section{IRRIGATION INTERVALS AND QUANTITIES}

One of the perceived advantages of LEPA over other methods was the ability to deliver light, uniform irrigations to ensure crop germination and growth while also taking advantage of seasonal rainfall in areas with marginal water supplies. Following initial development, LEPA irrigation management studies were conducted to determine optimum irrigation intervals as a function of irrigation availability in the Texas South Plains (TSP). From 1986 to 1988, Bordovsky et al. (1992) irrigated cotton at intervals ranging from 2 to 18 days with quantities varying from $40 \%$ to $100 \%$ of full irrigation (table 2). Values for "full irrigation" in the experiments were typically estimates of non-water-limiting crop water consumption determined by evapotranspiration-based irrigation scheduling methods (Allen et al., 1998). Due to inaccuracies in estimating actual crop water consumption, treatments often exceeded " $100 \%$ of full irrigation" to ensure maximum crop yield within an experiment. Treatments irrigated every 2 to 3 days resulted in higher yields than those watered at less frequent intervals. Irrigation quantities greater than $60 \%$ of full irrigation reduced cotton yields, which was attributed to excessive vegetative growth during the short growing seasons of the evaluation period.

Irrigation quantities on corn ranged from $40 \%$ to $130 \%$ of what was determined to be full irrigation and were applied with LEPA at intervals of 3 to 12 days (Lyle and Bordovsky, 1995).

Table 2. Studies comparing yields $\left(\mathrm{Mg} \mathrm{ha}^{-1}\right)$ of cotton lint, corn, and grain sorghum resulting from LEPA irrigation intervals and quantities.

\begin{tabular}{|c|c|c|c|c|c|c|c|c|c|c|c|}
\hline \multirow[b]{2}{*}{ Crop } & \multirow[b]{2}{*}{ Source } & \multirow{2}{*}{$\begin{array}{l}\text { Years of } \\
\text { Study }\end{array}$} & \multirow{2}{*}{$\begin{array}{c}\text { Average } \\
\text { Seasonal } \\
\text { Rainfall } \\
(\mathrm{mm})\end{array}$} & \multirow{2}{*}{$\begin{array}{c}\text { Average } \\
\text { Seasonal } \\
\text { Irrigation } \\
(\mathrm{mm})\end{array}$} & \multirow[b]{2}{*}{ Description } & \multicolumn{4}{|c|}{$\begin{array}{l}\text { Irrigation Interval } \\
\text { (days) }\end{array}$} & \multirow{2}{*}{$\begin{array}{l}\text { Average } \\
\text { of All } \\
\text { Irrigation } \\
\text { Intervals }\end{array}$} & \multirow[t]{2}{*}{$\begin{array}{l}\text { Average } \\
\text { Yield } \\
\text { Increase } \\
\text { from }<5 \mathrm{~d} \\
\text { Interval } \\
(\%)\end{array}$} \\
\hline & & & & & & $2-4$ & $5-7$ & $9-11$ & $12-18$ & & \\
\hline \multirow{6}{*}{$\begin{array}{l}\text { Cotton } \\
\text { lint }\end{array}$} & Bordovsky & 1986-1988 & 390 & 0 & Preplant irrig. & - & - & - & - & 0.85 & \\
\hline & et al., & & & 81 & $40 \%$ of full irrig. & 1.13 & 1.13 & 1.05 & 1.04 & 1.09 & 5.0 \\
\hline & 1992 & & & 121 & $60 \%$ of full irrig. & 1.08 & 1.08 & 1.01 & 1.01 & 1.05 & 4.5 \\
\hline & & & & 162 & $80 \%$ of full irrig. & 1.07 & 0.89 & 0.86 & 0.95 & 0.94 & 16.2 \\
\hline & & & & 202 & $100 \%$ of full irrig. & 0.94 & 0.87 & 0.85 & 0.95 & 0.90 & 5.4 \\
\hline & & & & & Average & 1.06 & 0.99 & 0.94 & 0.99 & & \\
\hline \multirow[t]{11}{*}{ Corn } & Spurgeon & 1989-1991 & 197 & 208 & $40 \%$ of full irrig. & 9.76 & 9.68 & 9.90 & - & 9.78 & -0.3 \\
\hline & and Makens, & & & 286 & $70 \%$ of full irrig. & 11.32 & 12.19 & 11.01 & - & 11.51 & -2.5 \\
\hline & 1991 & & & 443 & $100 \%$ of full irrig. & 13.12 & 12.75 & 12.57 & - & 12.81 & 3.5 \\
\hline & & & & 561 & $130 \%$ of full irrig. & 12.97 & 13.46 & 12.20 & - & 12.88 & 1.1 \\
\hline & & & & & Average & 11.79 & 12.02 & 11.42 & - & & \\
\hline & Lyle and & 1989-1991 & 250 & 0 & Preplant irrig. & - & - & - & - & 1.00 & \\
\hline & Bordovsky, & & & 147 & $40 \%$ of full irrig. & 8.40 & 8.70 & 8.20 & 8.00 & 8.33 & 1.2 \\
\hline & 1995 & & & 261 & $70 \%$ of full irrig. & 11.00 & 10.60 & 10.60 & 10.20 & 10.60 & 4.8 \\
\hline & & & & 368 & $100 \%$ of full irrig. & 12.00 & 12.20 & 11.40 & 10.90 & 11.63 & 4.2 \\
\hline & & & & 478 & $130 \%$ of full irrig. & 12.80 & 12.80 & 12.20 & 11.80 & 12.40 & 4.2 \\
\hline & & & & & Average & 11.05 & 11.08 & 10.60 & 10.23 & & \\
\hline \multirow{6}{*}{$\begin{array}{c}\text { Grain } \\
\text { sorghum }\end{array}$} & Bordovsky & $1992-1994$ & 170 & 0 & Preplant irrig. & - & - & - & - & 4.62 & \\
\hline & and Lyle, & & & 132 & $40 \%$ of full irrig. & 7.09 & 6.86 & 6.87 & 6.74 & 6.89 & 3.8 \\
\hline & 1996 & & & 230 & $70 \%$ of full irrig. & 7.72 & 7.45 & 7.48 & 7.41 & 7.52 & 3.5 \\
\hline & & & & 328 & $100 \%$ of full irrig. & 7.78 & 7.52 & 7.56 & 7.60 & 7.62 & 2.8 \\
\hline & & & & 427 & $130 \%$ of full irrig. & 7.67 & 7.67 & 7.42 & 7.57 & 7.58 & 1.5 \\
\hline & & & & & Average & 7.57 & 7.38 & 7.33 & 7.33 & & \\
\hline \multirow{3}{*}{\multicolumn{5}{|c|}{ Average yield reduction from $>4 \mathrm{~d}$ interval $(\%)$}} & Cotton lint & 0.0 & 6.5 & 12.0 & 7.1 & 8.5 & \\
\hline & & & & & Corn & 0.0 & -1.1 & 3.6 & 8.1 & 3.5 & \\
\hline & & & & & Grain sorghum & 0.0 & 2.6 & 3.2 & 3.2 & 3.0 & \\
\hline
\end{tabular}


Significant declines in grain yield occurred in treatments irrigated at intervals greater than 6 days. Howell et al. (1995) concluded that alternate-furrow LEPA systems should not exceed $25 \mathrm{~mm}$ per application, resulting in likely intervals of 3 to 4 days depending on gross irrigation capacity. However, Spurgeon and Makens (1991) found that LEPA irrigation intervals between 3.5 and 10.5 days did not greatly affect corn yields in experiments at Garden City, Kansas. Locations with soil water-holding capacities lower than these test locations may further benefit from more frequent irrigation intervals due to crops having more timely access to water. In all studies, average corn yields across irrigation intervals increased with irrigation quantity.

Evaluations of grain sorghum response to LEPA irrigation management occurred from 1992 to 1994 at Halfway, Texas (Bordovsky and Lyle, 1996). Irrigation intervals were 3.5 to 14 days with irrigation quantities at $40 \%, 70 \%, 100 \%$, and $130 \%$ of estimated full irrigation. At all irrigation levels, the highest average sorghum yields occurred at the 3.5-day interval (table 2). Total seasonal water use efficiency values were 1.69, 1.56, 1.36 , and $1.19 \mathrm{~kg} \mathrm{~m}^{-3}$ for the four respective irrigation levels.

Average yields of the various crops were increased from $2.5 \%$ to $16.2 \%$ by LEPA irrigation intervals of less than 5 days (table 2). The average yield reduction caused by irrigating at intervals $>4$ days was greatest for cotton at $8.5 \%$, while yield reductions for corn and grain sorghum were $3.5 \%$ and $3 \%$, respectively. Frequent irrigation intervals are desirable in reducing surface relocation of water from high-intensity LEPA application.

\section{LEPA IRRIGATION COMPARISON TO OTHER METHODS}

In replicated studies, the LEPA irrigation method has been compared to furrow, sprinkler (spray), and subsurface drip irrigation (SDI) methods in terms of the yield response of various crops irrigated at multiple levels or intervals (table 3). The first documented LEPA comparison was to overhead sprinkler and furrow methods in soybean (Lyle and Bordovsky, 1983). LEPA (with basin tillage), overhead sprinkler, and furrow irrigation resulted in yields of $2.63,2.00$, and $2.46 \mathrm{Mg} \mathrm{ha}^{-1}$, respectively, and net returns over irrigation expense of $\$ 1093, \$ 759$, and $\$ 971$ ha $^{-1}$.

Cotton yields from experiments irrigated with LEPA, SDI, MESA, and low-elevation spray (LESA) were compared in replicated trials (table 3). In evaluations of irrigation methods within an irrigation level, capacity, or interval, mean LEPA cotton yields were lower than those of SDI by an average of $12 \%$ and greater than those of MESA or LESA by $16 \%$. The differences among irrigation methods were largely attributed to respective differences in evaporation losses during and immediately following irrigation.

Sorghum and corn grain yield responses from field tests irrigated with LEPA, SDI, and sprinkler (overhead, MESA, and LESA) were akin to those of cotton in that LEPA yields were generally lower than those of SDI and greater than those of sprinkler methods (table 3 ). However, the respective differences among irrigation methods in the grain crops were limited to treatments irrigated at $50 \%$ or less of full irrigation. For example, within multi-year experiments (Schneider and Howell, 1995; Colaizzi et al., 2004; Schneider and Howell, 1998), the average yield increase for LEPA over sprinkler irrigation at $<50 \%$ of full irrigation was $16.5 \%$ and was attributed to less evaporation loss with LEPA. At $>50 \%$ of full irrigation in these same tests, the average yield advantage favored sprinkler irrigation over LEPA by $3 \%$. Colaizzi et al. (2004) suggested that at $100 \%$ irrigation, SDI and LEPA are more prone to deep percolation losses than sprinkler systems, resulting in less water availability and possible nutrient leaching. Another hypothesis was that elevated humidities, at high irrigation levels, in the grain crop canopies of the sprinkler treatments minimized stomatal closure, suppressing transpiration compared to LEPA treatments. Colaizzi et al. (2004) compared linear production functions of different irrigation methods derived from a threeyear grain sorghum experiment. Slopes of LEPA and SDI functions were slightly less than those of MESA and LESA, indicating that grain production was less responsive to variations in water delivered by LEPA and SDI and suggesting possible reductions in evaporation losses. Howell et al. (1995) showed that the slope of the grain yield to water use relationship for corn irrigated with LEPA was comparable to those reported in other studies for other irrigation methods.

The LEPA irrigation method provided no yield advantage over overhead sprinkler methods for experiments in which wheat (Schneider and Howell, 1997), sugarbeet, or malt barley (Stevens et al., 2015) were grown (table 3). However, in the same sugarbeet and malt barley experiments, Upendra et al. (2013) found that the microbial biomass carbon at 0 to $5 \mathrm{~cm}$ and the microbial biomass nitrogen at 10 to $20 \mathrm{~cm}$ were greater for the LEPA treatments than for the MESA treatments. They concluded that LEPA delivered water at a slower rate near the soil surface, which promoted microbial biomass and activity relative to $\mathrm{C}$ and $\mathrm{N}$ storage.

The results of these experiments indicated advantages of LEPA over sprinkler methods in most summer crops where the expected irrigation capacity can only supplement rainfall up to $75 \%$ of the maximum crop water requirement. On average, LEPA resulted in a $16 \%$ yield increase over sprinkler methods, and SDI resulted in a $14 \%$ yield increase over LEPA in irrigation treatments having $\leq 50 \%$ of the full irrigation quantity (table 3). At irrigation levels $>50 \%$ of full irrigation, crop yields of sprinkler treatments slightly exceeded those of LEPA, and SDI yields were $7 \%$ greater than LEPA.

\section{LEPA AS A PLATFORM FOR MORE COMPLEX SYSTEMS Multifunction Irrigation and Chemigation System}

To increase the utility of tower-truss irrigation systems and encourage the transition away from inefficient furrow irrigation, Lyle and Bordovsky (1986a) developed the multifunction irrigation system (MFIS). The MFIS applied chemical solutions through a dynamic nozzle network from the same moving tower-truss structure used for LEPA (fig. 5). The network of chemical nozzles "painted" targeted foliage with low volumes of spray solutions as they moved up and down vertically while the irrigation system advanced through the field. The "startstop" method of irrigation system alignment was replaced with a two-speed transmission/switching mechanism at each tower powered by variable-speed motors and controls allowing uniform, low-volume foliar applications (Lyle and Bordovsky, 1988). This provided efficient LEPA irrigation and precise foliar coverage of potential water-conserving chemicals such as anti-transpirants, growth regulators, and soil surface evaporation suppressants on target surfaces. Lithium salt tracers were 
Table 3. Average annual crop yield response $\left(\mathrm{Mg} \mathrm{ha}^{-1}\right)$ from experiments comparing LEPA to other irrigation methods.

\begin{tabular}{|c|c|c|c|c|c|c|c|c|c|c|c|c|c|}
\hline \multirow{3}{*}{$\begin{array}{l}\text { Crop and Source } \\
\text { (Years of Study) }\end{array}$} & \multirow{3}{*}{$\begin{array}{c}\text { Average } \\
\text { Seasonal } \\
\text { Rainfall } \\
(\mathrm{mm}) \\
\end{array}$} & \multirow{3}{*}{$\begin{array}{c}\text { Average } \\
\text { Seasonal } \\
\text { Irrigation } \\
(\mathrm{mm}) \\
\end{array}$} & \multirow[b]{3}{*}{ Description } & \multicolumn{7}{|c|}{ Irrigation Methods } & \multirow{2}{*}{\multicolumn{3}{|c|}{$\begin{array}{l}\text { Average Yield Increase } \\
\text { with LEPA Compared } \\
\text { to Others Method (\%) }\end{array}$}} \\
\hline & & & & \multicolumn{2}{|c|}{ LEPA } & \multirow[b]{2}{*}{ SDI } & \multicolumn{3}{|c|}{ Sprinkler } & \multirow[b]{2}{*}{ Furrow } & & & \\
\hline & & & & Sock & Bubble & & Overhead & MESA & LESA & & Sprinkler & SDI & Furrow \\
\hline \multicolumn{14}{|l|}{ Soybean } \\
\hline Lyle and & \multirow[t]{2}{*}{ - } & 362 & Basin tillage & - & 2.63 & - & 2.21 & - & - & 2.39 & 19 & - & 0.10 \\
\hline $\begin{array}{l}\text { Bordovsky, } \\
1983 \\
(1980-1981) \\
\end{array}$ & & 364 & Conventional tillage & - & 2.29 & - & 2.00 & - & - & 2.46 & 15 & - & -0.07 \\
\hline \multicolumn{14}{|l|}{ Cotton lint } \\
\hline \multirow{6}{*}{$\begin{array}{l}\text { Lyle et al., } \\
1995 \\
(1990-1994)\end{array}$} & \multirow[t]{6}{*}{213} & 0 & Preplant only & 0.31 & - & - & - & - & 0.00 & - & - & - & - \\
\hline & & 97 & $25 \%-30 \%$ of full irrig. & 0.79 & - & - & - & - & 0.61 & - & 30 & - & - \\
\hline & & 152 & $50 \%-60 \%$ of full irrig. & 0.86 & - & - & - & - & 0.68 & - & 26 & - & - \\
\hline & & 236 & $75 \%$ of full irrig. & 1.07 & - & - & - & - & 0.87 & - & 23 & - & - \\
\hline & & 287 & $90 \%-100 \%$ of full irrig. & 1.13 & - & - & - & - & 1.07 & - & 6 & - & - \\
\hline & & 427 & $120 \%-125 \%$ of full irrig. & 1.47 & - & - & - & - & 1.39 & - & 6 & - & - \\
\hline & - & 117 & $2.5 \mathrm{~mm} \mathrm{~d}^{-1}$ capacity & 1.05 & - & 1.28 & - & - & - & - & - & -18 & - \\
\hline and Lyle, & & 170 & $5.1 \mathrm{~mm} \mathrm{~d}^{-1}$ capacity & 1.26 & - & 1.37 & - & - & - & - & - & -8 & - \\
\hline 1998 & & 180 & $7.6 \mathrm{~mm} \mathrm{~d}^{-1}$ capacity & 1.31 & - & 1.41 & - & - & - & - & - & -7 & - \\
\hline & & 156 & $1 \mathrm{~d}$ LEPA interval & 1.20 & - & 1.36 & - & - & - & - & - & -12 & - \\
\hline & & 156 & $2 \mathrm{~d}$ LEPA interval & 1.21 & - & 1.36 & - & - & - & - & - & -11 & - \\
\hline & & 156 & $3 \mathrm{~d}$ LEPA interval & 1.20 & - & 1.36 & & - & - & - & - & -12 & - \\
\hline Bordovsky & 184 & 204 & Limited preplant irrig. & 0.95 & - & 1.14 & - & - & 0.83 & - & 14 & -17 & - \\
\hline and Porter, & & 204 & Full preplant irrig. & 1.05 & - & 1.18 & - & - & 0.95 & - & 11 & -11 & - \\
\hline 2003 & & 158 & $2.5 \mathrm{~mm} \mathrm{~d}^{-1}$ capacity & 0.85 & - & 1.01 & - & - & 0.71 & - & 20 & -16 & - \\
\hline$\underline{(1999-2001)}$ & & 250 & $5.1 \mathrm{~mm} \mathrm{~d}^{-1}$ capacity & 1.14 & - & 1.31 & - & - & 1.07 & - & 7 & -13 & - \\
\hline Colaizzi & 323 & 67 & $25 \%$ of full irrig. & 0.55 & - & 0.64 & - & 0.46 & 0.49 & - & 16 & -14 & - \\
\hline et al., 2010 & & 111 & $50 \%$ of full irrig. & 0.74 & - & 0.80 & - & 0.56 & 0.56 & - & 32 & -8 & - \\
\hline (2003-2004, & & 156 & $75 \%$ of full irrig. & 0.87 & - & 1.02 & - & 0.78 & 0.75 & - & 14 & -15 & - \\
\hline 2006-2007) & & 201 & $100 \%$ of full irrig. & 0.99 & - & 1.07 & - & 0.87 & 0.89 & - & 13 & -7 & - \\
\hline Grain sorghum & & & & & & & & & & & & & \\
\hline Schneider & 288 & 72 & $25 \%$ of full irrig. & 6.01 & - & - & 4.90 & - & - & - & 23 & - & - \\
\hline and Howell, & & 144 & $50 \%$ of full irrig. & 8.41 & - & - & 7.13 & - & - & - & 18 & - & - \\
\hline 1995 & & 216 & $75 \%$ of full irrig. & 8.49 & - & - & 8.24 & - & - & - & 3 & - & - \\
\hline (1992-1993) & & 288 & $100 \%$ of full irrig. & 8.59 & & - & 9.06 & - & - & - & -5 & - & - \\
\hline & & 180 & Avg. of four irrig. levels & 7.87 & 7.82 & - & 7.33 & - & 7.24 & - & 8 & - & - \\
\hline Colaizzi & 193 & 177 & $25 \%$ of full irrig. & 4.03 & - & 6.14 & - & 3.75 & 3.07 & - & 18 & -34 & - \\
\hline et al., 2004 & & 275 & $50 \%$ of full irrig. & 7.84 & - & 8.69 & - & 7.61 & 6.75 & - & 9 & -10 & - \\
\hline$(2000-2002)$ & & 373 & $75 \%$ of full irrig. & 8.74 & - & 8.77 & - & 9.40 & 8.92 & - & -5 & 0 & - \\
\hline & & 471 & $100 \%$ of full irrig. & 9.05 & - & 8.94 & - & 10.05 & 9.62 & - & -8 & 1 & - \\
\hline Corn & & & & & & & & & & & & & \\
\hline Schneider & 307 & 133 & $25 \%$ of full irrig. & 2.30 & 1.57 & - & 1.69 & - & 1.33 & - & 28 & - & - \\
\hline and Howell, & & 266 & $50 \%$ of full irrig. & 8.63 & 8.05 & - & 7.78 & - & 8.41 & - & 3 & - & - \\
\hline 1998 & & 399 & $75 \%$ of full irrig. & 11.99 & 11.23 & - & 11.54 & - & 11.14 & - & 2 & - & - \\
\hline (1994-1995) & & 532 & $100 \%$ of full irrig. & 12.76 & 13.43 & - & 14.29 & - & 13.65 & - & -6 & - & - \\
\hline Wheat & & & & & & & & & & & & & \\
\hline Schneider & 182 & 121 & $33 \%$ of full irrig. & 4.05 & 3.62 & - & 3.98 & - & - & - & -4 & - & - \\
\hline and Howell, & & 242 & $66 \%$ of full irrig. & 4.58 & 4.64 & - & 5.00 & - & - & - & -8 & - & - \\
\hline 1997 & & 363 & $100 \%$ of full irrig. & 4.48 & 4.51 & - & 5.28 & - & - & - & -15 & - & - \\
\hline (1994-1995, & & 263 & $100 \%$ delay irrig. & 4.38 & 4.52 & - & 4.36 & - & - & - & 2 & - & - \\
\hline one year) & & 300 & $100 \%$ early term. & 4.33 & 4.38 & - & 4.43 & - & - & - & -2 & - & - \\
\hline Sugarbeet & & & & & & & & & & & & & - \\
\hline $\begin{array}{l}\text { Stevens } \\
\text { et al., 2015 } \\
(2004-2008) \\
\end{array}$ & 179 & 248 & $100 \%$ of full irrig. & & 59.20 & - & - & 58.50 & - & - & 1 & - & - \\
\hline Malt barley & & & & & & & & & & & & & \\
\hline $\begin{array}{l}\text { Stevens } \\
\text { et al., 2015 } \\
(2005-2008) \\
\end{array}$ & - & 106 & $100 \%$ of full irrig. & & 5.92 & - & - & 5.76 & - & - & 3 & - & - \\
\hline & & & & & Aver: & of in & ation treatm & nts $\leq 50 \%$ & of full in & gation & 16 & -14 & - \\
\hline & & & & & Avera & e of Irr & ation treatm & nts $>50 \%$ & of full ir & gation & 3 & -7 & - \\
\hline
\end{tabular}

used in demonstrating that the MFIS dynamic nozzle application resulted in a two-fold coverage improvement over stationary application and a four-fold coverage improvement over aerial application (Lyle and Bordovsky, 1986b). Bynum et al. (1988) documented greenbug (Schizaphis graminum (Rondani)) control at $1 / 8$ to $1 / 16$ of the registered rate of chlorpyrifos when applied through the MFIS.
Excellent low-volume chemical coverage with MFIS resulted in the development of manually adjustable, in-canopy nozzle packages (fig. 6). This system used the LEPA drop and applicator near the soil surface as a platform to attach an auxiliary nozzle that flowed at approximately $1 / 4$ the water volume of the LEPA irrigation nozzle. Modification of a prototype pivot with a constant-move drive system and larger motors quadrupled standard pivot speeds, further reducing 


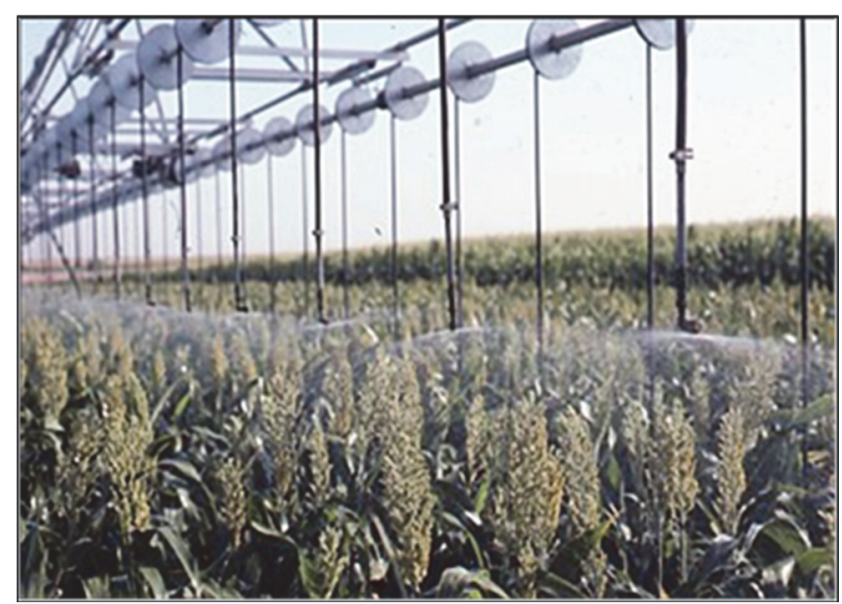

Figure 5. Multifunction irrigation and chemigation system (MFIS) applying low-volume solution to grain sorghum canopy. Auxiliary chemical nozzles automatically turned on and off while oscillating over a preset range as the MFIS moved through a field at the Texas A\&M AgriLife Research Center, Halfway, Texas.

chemigation solution volumes from 23 to $1.4 \mathrm{~m}^{3} \mathrm{ha}^{-1}$ and providing excellent foliar coverage while reducing non-target application. Using this system in experiments, spider mite (Tetranynchus urticae Koch) and southwestern corn borer (Diatraea grandiosella) were targeted with labeled chemical solutions, and pest control was achieved at low rates that gave no control with overhead chemigation (Lyle et al., 1989).

Several manufacturers currently provide LEPA applicators with alternative operational modes (Quad Spray, Senninger, Clermont, Fla.) or additional attachments (multi-trajectory splash plates, etc., Nelson Irrigation, Walla Walla, Wash.) that divert irrigation water upward for foliar chemigation applications. Experiments have shown the benefits of upward water spray on plant surfaces. For example, during the cotton fiber spinning process, sugar residues on cotton lint from aphids (Aphis gossypii Glover) and silver whitefly (Bemisia argentifolii Bellows and Perring) accumulate on equipment and interfere with processing (Perkins, 1991). In replicated tests, upwardly directed water from LEPA chemigation applicators located $20 \mathrm{~cm}$ above the soil surface were compared to MESA application in efforts to "wash" honey-

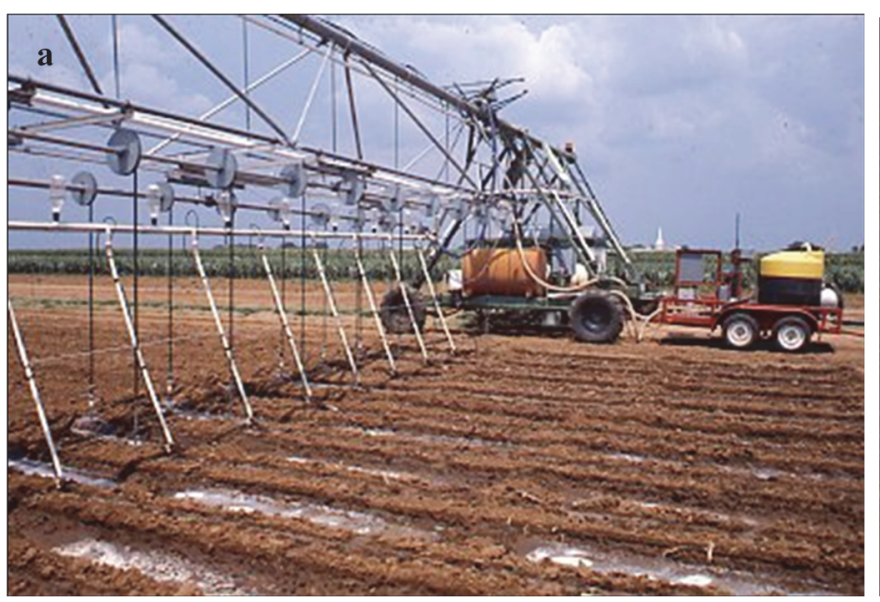

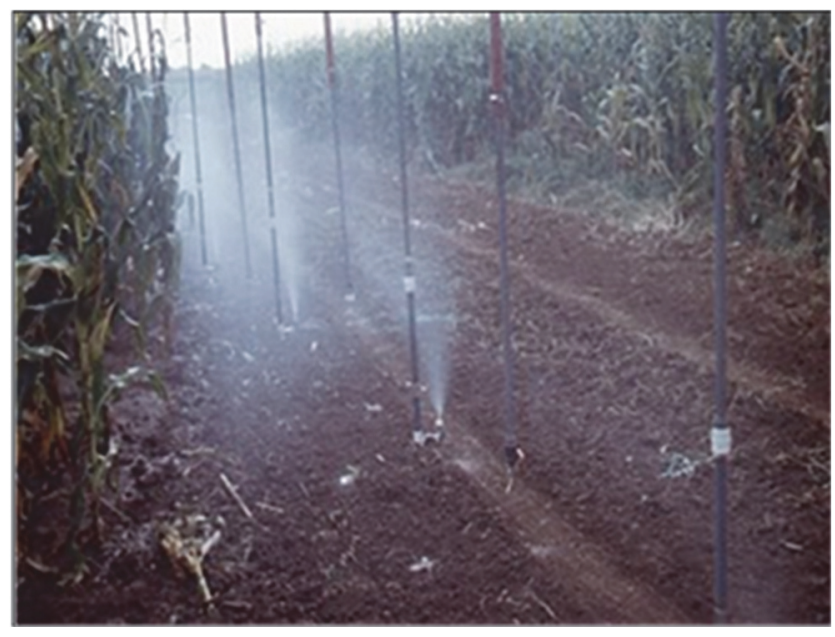

Figure 6. Stationary in-canopy chemigation nozzles on LEPA style drops at the Texas A\&M AgriLife Research Center, Halfway, Texas.

dew sugars from cotton lint of open bolls. The LEPA chemigation system reduced sugar spots by up to $96 \%$ over control treatments (Arnold et al., 2002).

\section{Planting}

An additional effort to use tower-truss irrigation platforms and a product derivative of the LEPA concept was the mobile irrigator planting system (MIPS). The MIPS consisted of a seed germination/gel mixing system, a non-destructive seed transfer and injection system, and a seed distribution and planting system located on a continuous-move irrigation system (Lyle et al., 1990; Lyle and Bordovsky, 1991). Field trials using a $182 \mathrm{~m}$ prototype irrigator produced plant stands and yields of cotton, corn, and sorghum comparable to those planted with a conventional planter (fig. 7). The concept was to develop irrigation machines capable of performing all functions necessary to produce crops, replacing high-horsepower tractors and multiple pieces of equipment. This system was destroyed by high winds, and the research project was terminated.

\section{MESA-LEPA Irrigation System}

A MESA-LEPA sprinkler system was developed to evaluate irrigation management in a complex agronomic re-

Figure 7. (a) Mobile irrigator planting system (MIPS) dispensing pre-germinated seed into a water excavated trench as irrigation occurred and (b) corn planted into residue of grain sorghum and cotton, all planted with the MIPS at the Texas A\&M AgriLife Research, Halfway, Texas. 
search project (Evans et al., 2010). The system used a programmable logic controller-based system that activated networks of control valves at field positions determined by onboard GPS on a tower-truss irrigation system. At farm scale, the ability to switch automatically from MESA to LEPA based on irrigation system position and an application map could provide LEPA use on areas with little slope and MESA use on steeper landscapes.

\section{OTHER IRRIGATION RESEARCH}

Water was distributed using LEPA in a site-specific manner in projects at the Texas A\&M AgriLife Research Center at Halfway, Texas. The applications were a function of soil water-holding capacity and topography with the goal of improving overall water use efficiency (WUE) (Bordovsky and Lascano, 2003). Multi-year results showed no significant increase in total lint yield or irrigation water productivity over uniform LEPA applications. In a related study, Booker et al. (2006) concluded that cotton plants appear to be too unpredictable to manage with site-specific irrigation under the deficit irrigation, short-growing season conditions of the Texas High Plains. However, O'Shaughnessy and Evett (2010) used a canopy temperature-based system to schedule sitespecific LEPA irrigations of cotton at Bushland, Texas, and concluded that this or similar methods might lead to successful auto-irrigation of short-season cotton in arid regions.

Crop coefficients $\left(K_{c}\right)$ are the ratio of crop evapotranspiration $\left(\mathrm{ET}_{c}\right)$ to reference evapotranspiration $\left(\mathrm{ET}_{o}\right)$ (Allen et al., 1998) and are commonly used to estimate crop water requirements. The LEPA method was used in developing $K_{c}$ functions at Uvalde, Texas, for cotton and wheat (Ko et al., 2009), with some $K_{c}$ values corresponding to those from FAO-56 and from the Texas High Plains and some that did not. Yazar et al. (1999) evaluated the crop water stress index (CWSI) for LEPA-irrigated corn on a clay loam soil. Minimal yield reductions occurred at CWSI threshold values of less than 0.33 , which was in line with studies using surface trickle irrigation methods on corn (Steele et al., 1994; Stegman, 1986). With LEPA as the irrigation method, Schneider and Howell (1998) and Howell et al. (1995) published water use functions for corn, and Colaizzi et al (2004) published water use functions for grain sorghum.

The LEPA method was used in irrigation timing experiments on cotton with 27 irrigation regimes evaluated at Halfway, Texas (Bordovsky et al., 2015a). In each year, cotton yield and water productivity data indicated that attempting to increase soil water in the root zone, or irrigating at greater than the cotton evapotranspiration rate, early in the growing season reduced the irrigation water value, or the gross crop value per unit of irrigation applied to that treatment, compared to delaying seasonal irrigation. This was partially attributed to high evaporation losses in May and June even with LEPA.

LEPA was used in crop rotation experiments evaluating water use among drought-tolerant crops where the primary water resource was rainfall supplemented by very limited irrigation (Bordovsky et al., 2015b). Seasonal irrigation volumes were limited to 0,76 , and $152 \mathrm{~mm}$ per year. In all years, increases in WUE occurred with each incremental increase in seasonal irrigation, indicating that concentrating the available irrigation, even with significant seasonal rain, was better than irrigating larger areas with less water.

Mobile drip irrigation (MDI) uses center pivots to advance sections of drip irrigation lines along the soil surface, with the drip lines replacing typical irrigation application devices (Olson and Rogers, 2008). In many respects, MDI can be considered a LEPA method in that MDI delivers water directly to the soil surface, reducing evaporative losses compared to spray methods. One difference between LEPA and MDI is the greater opportunity time for irrigation infiltration with MDI, because water is dispensed along the entire length of the drip line, as compared to LEPA. LEPA's advantages include soil surface modifications that potentially retain more rainfall. Olson and Rogers (2008) showed no significant differences in corn yield between MDI and standard flat spray nozzles; however, MDI emitter flows decreased over the test period due to clogging, implying possible higher water productivity with MDI than with spray applicators. A 2015 corn study with irrigation capacity treatments limited to $3.1 \mathrm{~mm} \mathrm{~d}^{-1}$ resulted in MDI having $35 \%$ lower soil water evaporation and significantly greater end-of season soil water compared to LESA (Kisekka et al., 2017). In a similar 2015-2016 corn study, MDI resulted in greater WUE than either LESA or LEPA in the dryer 2016 growing season (O'Shaughnessy and Colaizzi, 2017). Comparisons of LEPA to MDI at Halfway, Texas, showed no consistent differences in yield between the two methods for grain sorghum or cotton (table 4). The MDI method may be a reasonable choice in fields that have a combination of heavy-textured soils, slopes greater than $1 \%$, and limited irrigation capacity.

\section{SUMMARY AND CONCLUSIONS}

Forty years ago (ca. 1978), the LEPA irrigation concept was developed to address the depletion of available irrigation water from the Ogallala Aquifer and the sharp increase in pumping costs caused by the 1970s fuel crisis in the Texas High Plains. Rather than spraying water into the air at moderate to high pressures, the LEPA method applied water to the soil surface at low pressure as a tower-truss irrigation system moved through the field. Soil surface modifications and irrigator speed were used to ensure infiltration. Field evaluations documented non-uniformity of water in the direction of system movement; however, on landscapes of less than $1 \%$ slope, negative crop yield effects due to surface relocation of water were overcome by using appropriately spaced furrow checks (basin tillage), reservoir tillage, or infurrow crop residue management coupled with non-runoff producing irrigation amounts over the course of the growing season. Field tests on clay loam soils showed no consistent yield advantage at any level of irrigation by placing water in every furrow ( $1 \mathrm{~m}$ spacing) compared to alternate furrows (2 m spacing), where alternate-furrow water application reduced drop and applicator costs by half. Crop yields were decreased by up to $16.2 \%$ by LEPA irrigation intervals greater than 4 days. Frequent irrigation intervals are desirable in reducing surface relocation of water from high-intensity LEPA application. On average, LEPA resulted in a $16 \%$ yield increase over sprinkler methods, and SDI resulted in a 
Table 4. Cotton lint and grain sorghum yield, seasonal irrigation water use efficiency (SIWUE), and cotton loan value for cropping sequences with water delivered by LEPA and mobile drip irrigation (MDI) applicators at the Helm Farm of Texas A\&M AgriLife Research, 2016-2017. ${ }^{[a]}$

\begin{tabular}{|c|c|c|c|c|c|c|c|c|c|c|}
\hline & \multirow[b]{2}{*}{ Year } & \multirow[b]{2}{*}{ Crop } & \multirow[b]{2}{*}{ Cropping Sequence } & \multirow{2}{*}{$\begin{array}{l}\text { Irrigation } \\
\text { Strategy }\end{array}$} & \multicolumn{2}{|c|}{$\begin{array}{l}\text { Grain or Lint Yield } \\
\left(\mathrm{Mg} \mathrm{ha}^{-1}\right)\end{array}$} & \multicolumn{2}{|c|}{$\begin{array}{l}\text { SIWUE } \\
\left(\mathrm{kg} \mathrm{m}^{-3}\right)\end{array}$} & \multicolumn{2}{|c|}{$\begin{array}{c}\text { Cotton Loan Value } \\
\left(\$ \mathrm{~kg}^{-1}\right)\end{array}$} \\
\hline & & & & & LEPA & MDI & LEPA & MDI & LEPA & MDI \\
\hline & \multirow[t]{5}{*}{2016} & \multirow[t]{4}{*}{ Cotton } & Continuous cotton & Late start ${ }^{[b]}$ & $2.21 \mathrm{a}$ & $2.30 \mathrm{a}$ & $0.78 \mathrm{a}$ & $0.82 \mathrm{a}$ & $1.29 \mathrm{a}$ & $1.30 \mathrm{a}$ \\
\hline & & & in terminated wheat & Regular start & $2.12 \mathrm{~b}$ & $2.29 \mathrm{a}$ & $0.66 \mathrm{~b}$ & $0.75 \mathrm{a}$ & $1.27 \mathrm{a}$ & $1.30 \mathrm{a}$ \\
\hline & & & $\begin{array}{l}\text { Cotton/grain sorghum } \\
\text { two-year rotation }\end{array}$ & Regular start & $1.19 \mathrm{a}$ & $1.32 \mathrm{a}$ & $0.05 \mathrm{a}$ & $0.12 \mathrm{a}$ & $1.16 \mathrm{a}$ & $1.15 \mathrm{a}$ \\
\hline & & & $\begin{array}{l}\text { Cotton/wheat (harvested) } \\
\text { two-year rotation }\end{array}$ & Regular start & $1.53 \mathrm{a}$ & $1.50 \mathrm{a}$ & $0.14 \mathrm{a}$ & $0.13 \mathrm{a}$ & $1.16 \mathrm{a}$ & $1.16 \mathrm{a}$ \\
\hline & & $\begin{array}{c}\text { Grain } \\
\text { sorghum }\end{array}$ & $\begin{array}{l}\text { Grain sorghum/cotton } \\
\text { two-year rotation }\end{array}$ & Regular start & $5.67 \mathrm{a}$ & $5.62 \mathrm{a}$ & $0.69 \mathrm{a}$ & $0.66 \mathrm{a}$ & - & - \\
\hline & \multirow[t]{5}{*}{2017} & \multirow[t]{4}{*}{ Cotton } & Continuous cotton & Regular start & $1.03 \mathrm{a}$ & $1.15 \mathrm{a}$ & $0.34 \mathrm{a}$ & $0.48 \mathrm{a}$ & $1.15 \mathrm{a}$ & $1.15 \mathrm{a}$ \\
\hline & & & $\begin{array}{l}\text { Continuous cotton } \\
\text { in terminated wheat }\end{array}$ & Regular start & $1.37 \mathrm{a}$ & $1.32 \mathrm{a}$ & $0.80 \mathrm{a}$ & $0.74 \mathrm{a}$ & $1.18 \mathrm{a}$ & $1.20 \mathrm{a}$ \\
\hline & & & $\begin{array}{l}\text { Cotton/grain sorghum } \\
\text { two-year rotation }\end{array}$ & Regular start & $1.41 \mathrm{a}$ & $1.36 \mathrm{a}$ & $0.43 \mathrm{a}$ & $0.37 \mathrm{a}$ & $1.17 \mathrm{a}$ & $1.15 \mathrm{a}$ \\
\hline & & & $\begin{array}{l}\text { Cotton/wheat (harvested) } \\
\text { two-year rotation }\end{array}$ & Regular start & $1.49 \mathrm{a}$ & $1.41 \mathrm{a}$ & $0.44 \mathrm{a}$ & $0.35 \mathrm{a}$ & $1.21 \mathrm{a}$ & $1.15 \mathrm{a}$ \\
\hline & & $\begin{array}{c}\text { Grain } \\
\text { sorghum }\end{array}$ & $\begin{array}{l}\text { Grain sorghum/cotton } \\
\text { two-year rotation }\end{array}$ & Regular start & $3.47 \mathrm{a}$ & $3.74 \mathrm{a}$ & $2.22 \mathrm{a}$ & $2.51 \mathrm{a}$ & - & - \\
\hline
\end{tabular}

$14 \%$ yield increase over LEPA in irrigation treatments having $\leq 50 \%$ of the full irrigation quantity. At irrigation levels $>50 \%$ of full irrigation, crop yields of sprinkler treatments approximately equaled those of LEPA, and SDI yields were $7 \%$ greater than LEPA. The LEPA irrigation method was the catalyst for innovations in chemigation, no-till planting, and site-specific irrigation. Since its introduction, the LEPA method has been used extensively in the Texas High Plains, in many states, and in several countries. LEPA continues to be an important water conservation tool in semi-arid regions facing declining irrigation availability.

\section{ACKNOWLEDGEMENTS}

This article represents a small part of the center-pivot irrigation technology transfer effort supported by the Ogallala Aquifer Program, a consortium between the USDA Agricultural Research Service, Kansas State University, Texas A\&M AgriLife Research, Texas A\&M AgriLife Extension Service, Texas Tech University, and West Texas A\&M University. The author also acknowledges support from the Texas State Support Committee of Cotton Inc., USDANIFA Ogallala Water CAP (2016-68007-25066), and USDA-NIFA (Project 1007927) through Texas A\&M AgriLife Research.

\section{REFERENCES}

Allen, R. G., Periera, L. S., Raes, D., \& Smith, M. (1998). Crop evapotranspiration: Guidelines for computing crop water requirements. Irrigation and Drainage Paper No. 56. Rome, Italy: United Nations FAO.

Arnold, M. D., Rummel, D. R., Bordovsky, J. P., Slosser, J. E., \& Carroll, S. C. (2002). Use of the center-pivot irrigation system for reduction of cotton aphid sugars on cotton lint. Southwest. Entomol., 27(1), 11-19.

Booker, J. D., Bordovsky, J., Lascano, R. J., \& Segarra, E. (2006). Variable-rate irrigation on cotton lint yield and fiber quality. Proc. Beltwide Cotton Conf. (pp. 1768-1776). Memphis, TN:
National Cotton Council.

Bordovsky, J. P., \& Lascano, R. J. (2003). Variable-rate irrigation using low-energy precision application (LEPA).(pp. 563-571) Proc. Beltwide Cotton Conf. Memphis, TN: National Cotton Council.

Bordovsky, J. P., \& Lyle, W. M. (1996). LEPA irrigation of grain sorghum with varying water supplies. Trans. ASAE, 39(6), 20332038. https://doi.org/10.13031/2013.27706

Bordovsky, J. P., \& Lyle, W. M. (1998). Cotton irrigation with LEPA and subsurface drip systems on the Southern High Plains. Proc. Beltwide Cotton Conf. (pp. 409-412). Memphis, TN: National Cotton Council.

Bordovsky, J. P., \& Porter, D. O. (2003). Cotton response to preplant irrigation level and irrigation capacity using spray, LEPA, and subsurface drip irrigation. ASAE Paper No. 032008. St. Joseph, MI: ASAE.

Bordovsky, J. P., Lyle, W. M., Bender, D. A., Lipe, W. N., Vrubel L., W., \& Lorenz, D. C. (1984). LEPA vs. drip irrigation methods. In Texas Agricultural Experiment Station Annual Progress Report (pp. 7-12). College Station, TX: Texas A\&M University.

Bordovsky, J. P., Lyle, W. M., Lascano, R. J., \& Upchurch, D. R. (1992). Cotton irrigation management with LEPA systems. Trans. ASAE, 35(3), 879-884. https://doi.org/10.13031/2013.28673

Bordovsky, J. P., Mustian, J. T., Ritchie, G. L., \& Lewis, K. L. (2015a). Cotton irrigation timing with variable seasonal irrigation capacities in the Texas south plains. Appl. Eng. Agric., 31(6), 883-897. https://doi.org/10.13031/aea.31.10953

Bordovsky, J. P., Winters, D., \& Mustian, J. T. (2015b). Cotton response in non-traditional crop rotations at low irrigation levels. ASABE Paper No. 152132333.. St. Joseph, MI: ASABE. https://doi.org/10.13031/irrig.20152132333

Buchleiter, G. W. (1992). Performance of LEPA equipment on center-pivot machines. Appl. Eng. Agric., 8(5), 631-637. https://doi.org/10.13031/2013.26135

Bynum Jr., E. D., Archer, T. L., Lyle, W. M., \& Bordovsky, J. P. (1988). Chlorpyrifos applications for Greenbug (Homoptera: Aphididae) control with a new multifunction irrigation system. J. Econ. Entomol., 81(6), 1781-1784. https://doi.org/10.1093/jee/81.6.1781 
Christiansen, J. E. (1942). Irrigation by sprinkling. Bulletin 670. Berkeley, CA: University of California Agricultural Experiment Station.

Coelho, R. D., Martin, D. L., \& Chaudrhy, F. H. (1996). Effect of LEPA irrigation on storage in implanted reservoirs. Trans. ASAE, 39(4), 1287-1298. https://doi.org/10.13031/2013.27620

Colaizzi, P. D., Evett, S. R., Howell, T. A., \& Baumhardt, R. L. (2010). Crop production comparison with spray, LEPA, and subsurface drip irrigation in the Texas High Plains. In M. Dukes (Ed.), Proc. 5th Natl. Irrig. Symp. St. Joseph, MI: ASABE.

Colaizzi, P. D., Schneider, A. D., Evett, S. R., \& Howell, T. A. (2004). Comparison of SDI, LEPA, and spray irrigation performance for grain sorghum. Trans. ASAE, 47(5), 1477-1492. https://doi.org/10.13031/2013.17628

EIA. (2018). U.S. natural gas wellhead price. Washington, DC: U.S. Energy Information Administration. Retrieved from https://www.eia.gov/dnav/ng/hist/n9190us3a.htm

Evans, R. G., Stevens, W. B., \& Iversen, W. M. (2010). Development of strip tillage on sprinkler irrigated sugarbeet. Appl. Eng. Agric., 26(1), 59-69.

https://doi.org/10.13031/2013.29476

Fangmeier, D. D., Vlotman, W. F., \& Eftekharzadeh, S. (1990). Uniformity of LEPA irrigation systems with furrow drops. Trans. ASAE, 33(6), 1907-1912. https://doi.org/10.13031/2013.31557

Fipps, G., \& New L., L. (1990). Six years of LEPA in Texas: Less water, higher yields. Proc. 3rd Natl. Irrig. Symp. (pp. 115-120). St. Joseph, MI: ASAE.

Hanson, B. R., Schwankl, L., \& Fulton, A. (1988). Uniformity of infiltrated water under a low-energy precision application (LEPA) irrigation system. Trans. ASAE, 31(5), 1463-1468. https://doi.org/10.13031/2013.30886

Hill, K., Segarra, E., Ervin, R. T., \& Lyle, W. M. (1990). Lowenergy precision application irrigation for cotton production in the Texas Southern High Plains. J. Agric. Nat. Res., 4, 40-42.

Howell, T. A. (2001). Enhancing water use efficiency in irrigated agriculture. Agron. J., 93(2), 281-289. https://doi.org/10.2134/agronj2001.932281x

Howell, T. A., Yazar, A., Schneider, A. D., Dusek, D. A., \& Copeland, K. S. (1995). Yield and water use efficiency of corn in response to LEPA irrigation. Trans. ASAE, 38(6), 1737-1747. https://doi.org/10.13031/2013.28001

Kisekka, I., Oker, T., Nguyen, G., Aguilar, J., \& Rogers, D. (2017). Revisiting precision mobile drip irrigation under limited water. Irrig. Sci., 35(6), 483-500. https://doi.org/10.1007/s00271-0170555-7

Ko, J., Piccinni, G., Marek, T., \& Howell, T. (2009). Determination of growth-stage-specific crop coefficients $\left(K_{c}\right)$ of cotton and wheat. Agric. Water Mgmt., 96(12), 1691-1697. https://doi.org/10.1016/j.agwat.2009.06.023

Lyle, W. M., \& Bordovsky, J. P. (1981). Low-energy precision application (LEPA) irrigation system. Trans. ASAE, 24(5), 12411245. https://doi.org/10.13031/2013.34427

Lyle, W. M., \& Bordovsky, J. P. (1983). LEPA irrigation system evaluation. Trans. ASAE, 26(3), 776-781. https://doi.org/10.13031/2013.34022

Lyle, W. M., \& Bordovsky, J. P. (1986a). Multifunction irrigation system development. Trans. ASAE, 29(2), 512-516. https://doi.org/10.13031/2013.30182

Lyle, W. M., \& Bordovsky, J. P. (1986b). Chemical application with the multifunction LEPA system. Trans. ASAE, 29(6), 16991706. https://doi.org/10.13031/2013.30376

Lyle, W. M., \& Bordovsky, J. P. (1988). Irrigation system for precise water and chemical application. U.S. Patent No. 4763836A.

Lyle, W. M., \& Bordovsky, J. P. (1991). Planting row crops with moving irrigation systems. Trans. ASAE, 34(6), 2404-2412. https://doi.org/10.13031/2013.31886

Lyle, W. M., \& Bordovsky, J. P. (1995). LEPA corn irrigation with limited water supplies. Trans. ASAE, 38(2), 455-462. https://doi.org/10.13031/2013.27853

Lyle, W. M., \& Dixon, D. R. (1977). Basin tillage for rainfall retention. Trans. ASAE, 20(6), 1013-1017, 1021 https://doi.org/10.13031/2013.35693

Lyle, W. M., Bordovsky, J. P., \& Butler, M. A. (1990). Row crop planting apparatus for mobile pipe span-and-tower irrigation systems. U.S. Patent No. 4970973A.

Lyle, W. M., Bynum Jr., E. D., Bordovsky, J. P., \& Archer, T. A. (1989). In-canopy chemigation with multifunction LEPA irrigation systems. Trans. ASAE, 32(6), 2009-2014. https://doi.org/10.13031/2013.31255

Lyle, W. M., Onken, A. B., \& Keeling, J. W. (1995). Summary of LEPA vs spray irrigation at AG-CARES. Dawson County 1994 Annual report for the agricultural complex for advanced research and extension systems. 1-6. College Station, TX: Texas Agricultural Experiment Station.

McGuire, V. L. (2017). Data used to map water-level changes in the High Plains aquifer, predevelopment (about 1950) to 2015 and 2013 to 2015. Reston, VA: U.S. Geological Survey. https://doi.org/10.5066/F7SB43WM

New, L., \& Fipps, G. (1991). LEPA conversion and management. Bulletin 1691. College Station, TX: Texas Agricultural Experiment.

Olson, B. L., \& Rogers, D. H. (2008). Comparing drag hoses verses sprinklers on corn irrigated by a center pivot. Appl. Eng. Agric., 24(1), 41-45. https://doi.org/10.13031/2013.24159

O'Shaughnessy, S. A., \& Colaizzi, P. D. (2017). Performance of precision mobile drip irrigation in the Texas High Plains region. Agron., 7(4), 68. https://doi.org/10.3390/agronomy7040068

O'Shaughnessy, S. A., \& Evett, S. R. (2010). Canopy temperature based system effectively schedules and controls center-pivot irrigation of cotton. Agric. Water Mgmt., 97(9), 1310-1316. https://doi.org/10.1016/j.agwat.2010.03.012

Perkins, H. H. (1991). Cotton stickiness: A major problem in modern textile processing. Proc. Beltwide Cotton Conf. (pp. 523-524). Memphis, TN: National Cotton Council.

Rawlins, S. L., Hoffman, G. J., \& Merrill, S. D. (1974). Traveling trickle system. Proc. 2nd Intl. Drip Irrig. Congress (pp. 184187). Riverside, CA: University of California.

Schneider, A. D. (2000). Efficiency and uniformity of the LEPA and spray sprinkler methods: A review. Trans. ASAE, 43(4), 937-944. https://doi.org/10.13031/2013.2990

Schneider, A. D., \& Howell, T. A. (1995). Grain sorghum response to sprinkler application methods and system capacity. Trans. ASAE, 38(6), 1693-1697. https://doi.org/10.13031/2013.27996

Schneider, A. D., \& Howell, T. A. (1997). Methods, amounts, and timing of sprinkler irrigation for winter wheat. Trans. ASAE, 40(1), 137-142. https://doi.org/10.13031/2013.21258

Schneider, A. D., \& Howell, T. A. (1998). LEPA and spray irrigation of corn: Southern High Plains. Trans. ASAE, 41(5), 1391-1396. https://doi.org/10.13031/2013.17313

Schneider, A. D., \& Howell, T. A. (2000). Surface runoff due to LEPA and spray irrigation of a slowly permeable soil. Trans. ASAE, 43(5), 1089-1095. https://doi.org/10.13031/2013.3001

Spurgeon, W. E., \& Makens, T. P. (1991). Irrigation management for LEPA systems. ASAE Paper No. 912519. St. Joseph, MI: ASAE.

Spurgeon, W. E., Feyerherm, A. A., \& Manges, H. L. (1995). Incanopy application mode and soil surface modification for corn. Appl. Eng. Agric., 11(4), 517-522.

https://doi.org/10.13031/2013.25771

Steele, D. D., Stegman, E. C., \& Gregor, B. L. (1994). Field 
comparison of irrigation scheduling methods for corn. Trans. ASAE, 37(4), 1197-1203. https://doi.org/10.13031/2013.28194

Stegman, E. C. (1986). Efficient irrigation timing methods for corn production. Trans. ASAE, 29(1), 203-210. https://doi.org/10.13031/2013.30127

Stevens, W. B., Evans, R. G., Iversen, W. M., Jabro, J. D., Sainju, U. M., \& Allen, B. L. (2015). Strip tillage and high-efficiency irrigation applied to a sugarbeet-barley rotation. Agron. J., 107(4), 1250-1258. https://doi.org/10.2134/agronj14.0525

Upendra, M. S., Stevens, W. B., Evans, R. G., \& Iversen, W. M. (2013). Irrigation system and tillage effects on soil carbon and nitrogen fractions. SSSA J., 77(4), 1225-1234.

https://doi.org/10.2136/sssaj2012.0412

Wilke, O. C. (1974). Mobile drip irrigation systems. Proc. 2nd Intl. Drip Irrig. Congress (pp. 188-192). Riverside, CA: University of California.

Wiser, T. B. (1985). Soil pitting and damming implement and process. U.S. Patent No. 4508177.

Yazar, A., Howell, T. A., Dusek, D. A., \& Copeland, K. S. (1999). Evaluation of crop water stress index for LEPA irrigated corn. Irrig. Sci., 18(4), 171-180. https://doi.org/10.1007/s002710050059 